\title{
PENINGKATAN EFISIENSI DAN EFEKTIFITAS LAYANAN DOSEN DALAM PEMANFAATAN WEB APPLICATION
}

\author{
Reina \\ Computer Science Department, School of Computer Science, Binus University \\ Jl. K.H. Syahdan No. 9, Palmerah, Jakarta Barat 11480 \\ reina@binus.edu
}

\begin{abstract}
This study aims to determine the benefits of a web application in improving the efficiency and effectiveness of services to lecturers. The research method consists of literature study and data collection analysis based on observations. Implementing a web application, an observation is conducted followed by a comparison on data prior to the implementation. The evaluation results show that the implementation of a web application improves efficiency and effectiveness in the use of time and resources in providing services to lecturers in information access.
\end{abstract}

Keywords: web application, efficiency, effectiveness, lecturer, information access

\begin{abstract}
ABSTRAK
Penelitian ini bertujuan untuk mengetahui manfaat web application dalam meningkatkan efisiensi dan efektifitas layanan kepada dosen. Metode penelitian yang digunakan terdiri dari tahapan studi pustaka, pengumpulan data, dan analisis berdasarkan observasi. Dari hasil implementasi web application, dilakukan pengamatan data dan komparasi dengan data sebelum implementasi. Hasil evaluasi menunjukkan bahwa dengan penerapan web application dapat meningkatkan efisiensi dan efektifitas dalam penggunaan waktu dan sumber daya untuk memberikan layanan kepada dosen dan memberikan kemudahan bagi dosen dalam mengakses informasi.
\end{abstract}

Kata kunci: web application, efisiensi, efektifitas, dosen, akses informasi 


\section{PENDAHULUAN}

Universitas Bina Nusantara sebagai salah satu universitas swasta terbesar di Jakarta dengan jumlah mahasiswa aktif lebih dari 20.000 per semester, mengelola dosen aktif mengajar sebesar 800 s.d. 900 dosen dan 250 s.d. 300 dosen penguji sidang skripsi/tugas akhir per semester. Proses untuk menjadwalkan dosen dalam mengajar dan menjadwalkan menguji sidang skripsi/tugas akhir sebelumnya dilakukan secara manual. Untuk dapat melakukan penjadwalan perlu dilakukan koordinasi yang baik dengan para dosen di mana dibutuhkan waktu kesediaan dosen untuk dapat dijadwalkan. Media komunikasi yang dipakai sebelumnya adalah formulir dalam bentuk kertas, sehingga menimbulkan banyaknya tahap kerja administratif yang harus dilakukan oleh staf dan tidak memberikan keleluasaan bagi dosen dalam menyampaikan data kesediaan karena bergantung pada formulir yang diberikan. Dengan jumlah dosen yang cukup besar, dibutuhkan waktu yang cukup relatif banyak untuk melakukan tahapan kerja administratif tersebut seperti yang terlihat pada Gambar 1.

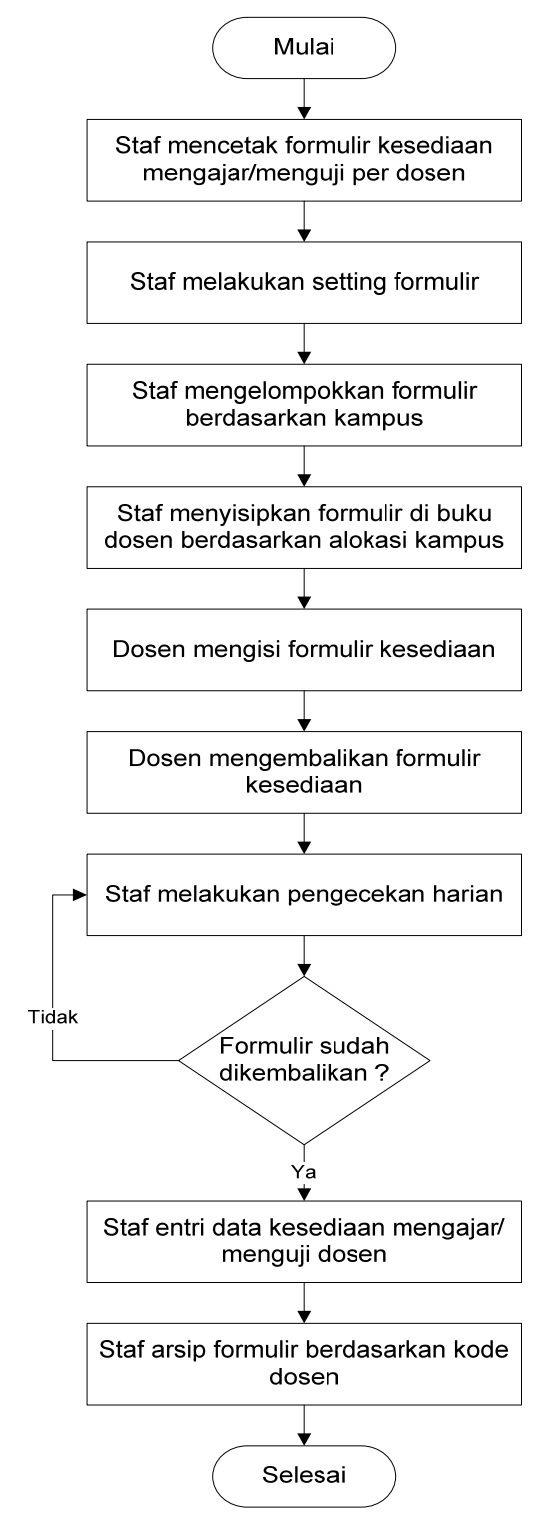

Gambar 1 Alur proses mendapatkan kesediaan waktu mengajar/menguji dosen secara manual 
Proses dalam mendapatkan informasi waktu kesediaan dosen untuk penjadwalan kuliah dan penjadwalan ujian skripsi dimulai dengan staf melakukan pencetakan formulir per dosen, melakukan setting formulir, mengelompokkan formulir berdasarkan kampus, menyisipkan formulir di dalam buku dosen berdasarkan alokasi kampus, melakukan pengecekan harian atas formulir isian yang telah dilakukan oleh dosen, meng-entry data isian dosen, dan melakukan pengarsipan berdasarkan kode dosen. Setelah proses penjadwalan dilakukan, hasil penjadwalan diinformasikan kepada dosen dalam bentuk surat dan didistribusikan ke masing-masing dosen. Setelah proses ujian skripsi selesai dilakukan, dosen akan menerima honor sebagai dosen pembimbing maupun penguji pada setiap bulannya. Informasi transaksi membimbing dan menguji serta honor yang didapat pun diberikan dalam bentuk slip honor hasil cetakan serta didistribusikan kepada semua dosen terkait.

Masalah lain yang timbul adalah saat pelaksanaan terkadang formulir kesediaan terselip dan tidak kembali lengkap untuk keseluruhan dosen yang dibutuhkan, sehingga staf harus melakukan pencetakan ulang dan melakukan ulang serangkaian tahapan dari proses tersebut. Selain dari sisi waktu, penggunaan sumber daya seperti penggunaan kertas, tinta, dan peralatan pendukung lainnya pun tidaklah sedikit. Analisis permasalahan yang ada dapat dilihat pada Gambar 2.

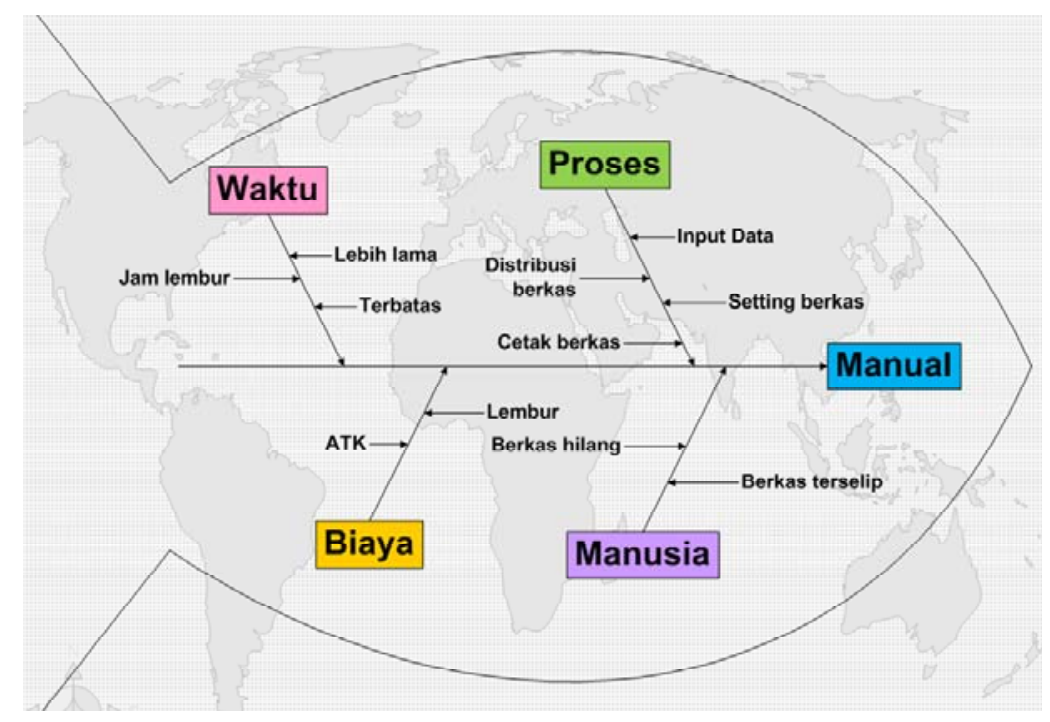

Gambar 2 Analisis permasalahan

Student Registration and Service Center (SRSC) sebagai unit yang mengelola penjadwalan kuliah dan penjadwalan ujian skripsi/tugas akhir memanfaatkan kemajuan teknologi yaitu web application untuk menunjang operasional dan melakukan berbagai inovasi guna meningkatkan layanan kepada dosen.

Dalam penelitian yang dilakukan oleh Suryane, data tentang proses akademik siswa masih dalam bentuk dokumen dan arsip. Sehingga Pengolahan data tidak efektif dan efisien. Oleh karena itu, diperlukan suatu program aplikasi yang khusus menangani seputar Sistem Informasi Akademik. Adapun hasil akhir dari penelitian tersebut, yakni dengan sistem informasi yang berjalan, masih terjadi keterlambatan informasi dan masih kurang cepatnya penyampaian informasi, yang kemudian dianalisis dan dirancang menjadi sistem informasi berbasis web yaitu suatu sistem informasi yang dapat mendukung perkembangan teknologi informasi yang diharapkan dapat mencapai kinerja yang diinginkan (Suryane, 2011). Web services are meant to provide an interface into applications built using today's object-based platforms like .NET, COM, and J2EE. In fact, a Web service can be anything that's accessible via the World Wide Web. (Wall \& Lader, 2002). 
Tujuan penelitian ini untuk mengukur efisiensi dan efektifitas layanan dosen dalam pemanfaatan web application.

\section{METODE}

Metode yang digunakan dalam penelitian ini meliputi beberapa tahapan. Tahap pertama adalah studi pustaka untuk merancang dan membuat web application. Perancangan yang dihasilkan selaras dengan kebutuhan dalam memberikan kemudahan bagi dosen dalam memberikan informasi kesediaan waktu untuk dapat dijadwalkan baik dalam penjadwalan kuliah mapun penjadwalan ujian, serta informasi hasil penjadwalan kepada dosen.

Tahap kedua adalah mempelajari proses bisnis yang ada untuk melakukan analisis kebutuhan sistem. Hasil observasi yang dilakukan mendapatkan beberapa hal yang menjadi kelemahan dari proses yang berjalan sebelumnya, yaitu proses dengan tahapan aktifitas yang cukup banyak, membutuhkan keberadaan dosen di kampus dalam berkoordinasi, input data yang dilakukan secara manual oleh staf, dan penggunaan sumber daya seperti kertas dan tinta printer yang cukup banyak.

Tahap ketiga adalah pengumpulan serta pengamatan data sebelum dan setelah sistem diterapkan guna mengukur tingkat efisiensi dan efektifitas pemanfaatan sistem. Data yang didapat adalah data tahun 2006 s.d. 2008. Di mana data September 2006 s.d. September 2007 adalah data sebelum implementasi sistem dan data Oktober 2007 s.d. September 2008 adalah data setelah implementasi sistem.

\section{HASIL DAN PEMBAHASAN}

\section{Pengembangan Aplikasi}

Untuk memberikan kemudahan bagi dosen dalam memberikan informasi waktu kesediaan mengajar dan menguji, dikembangkanlah web application di mana dosen dapat dengan mudah menyampaikan waktu kesediaan mengajar dan menguji melalui internet, dalam hal ini melalui http://binusmaya.binus.ac.id. Kelebihan lain yang didapat adalah adanya kemudahan dan keleluasaan pada aspek waktu di mana penyampaian data kesediaan dapat dilakukan sesuai periode yang diberikan di mana pun dosen berada, tidak harus pada saat berada di kampus.

Dengan adanya aplikasi, tahapan kerja administratif staf mulai dari penyiapan formulir sampai entri data dan arsip formulir pun sudah tidak perlu dilakukan karena data secara otomatis tersimpan dan siap untuk digunakan. Hal ini menyebabkan dapat dieliminasinya kebutuhan sumber daya seperti kertas, tinta, dan peralatan pendukung lainnya. Proses kerja pun sangatlah menjadi sederhana seperti yang digambarkan dalam Gambar 3 di mana staf hanya cukup melakukan transfer data dari database ke web server dan setting periode pengisian serta melakukan transfer data hasil pengisian dari web server ke database server. Melalui aplikasi yang dikembangkan, dosen tidak hanya dapat memberikan data kesediaan mengajar atau menguji, melainkan mendapatkan berbagai informasi yang selama ini disampaikan secara manual. Ada empat informasi yang dapat diakses oleh para dosen, yaitu jadwal mengawas ujian mata kuliah, jadwal menguji skripsi, rincian transaksi dan honor membimbing dan menguji, serta buku petunjuk dan prosedur skripsi untuk diketahui para dosen. Di mana sebelum implementasi, untuk menyajikan informasi tersebut kepada dosen dibutuhkan banyak kerja administratif yang menyita waktu serta sumber daya yang tidaklah sedikit. Dengan tersedianya melalui web application, dosen dapat mengakses informasi kapan pun dan di mana pun. 


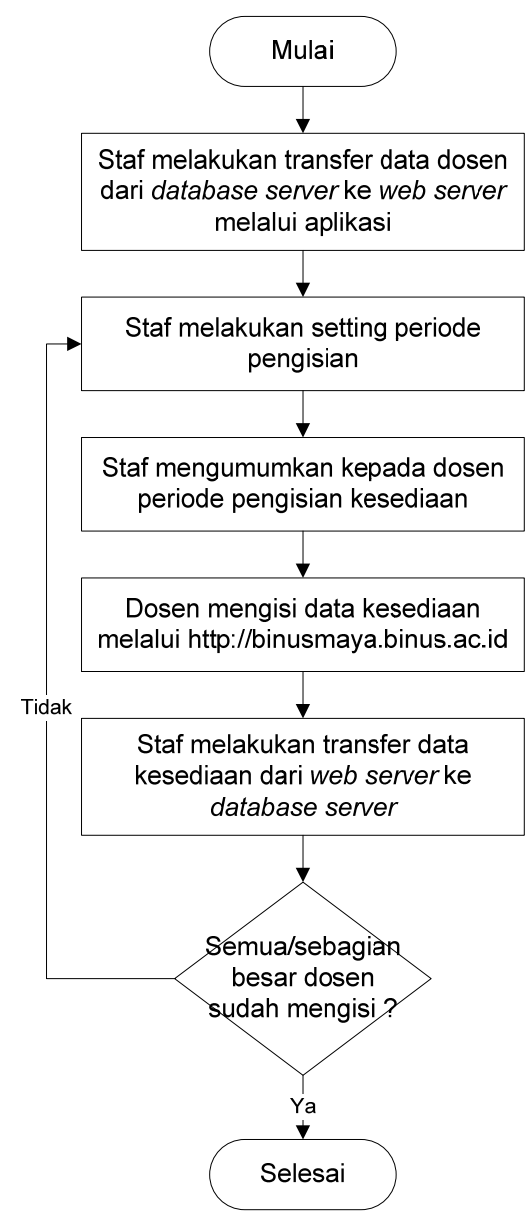

Gambar 3 Alur proses untuk mendapatkan kesediaan waktu mengajar/menguji dosen setelah pengembangan sistem

\section{Evaluasi Efisiensi dan Efektifitas Kerja serta Sumber Daya}

Data tahun 2006 s.d. 2007 (data sebelum implementasi aplikasi) dan data tahun 2007 s.d. 2008 (data setelah aplikasi diimplementasi) yang diamati sebagai perbandingan, menunjukkan terjadinya efisiensi penggunaan waktu dan sumber daya yang tidaklah sedikit. Tabel 1 menjelaskan data implementasi untuk kesediaan mengajar yang didapat melalui aplikasi dan Tabel 2 menjelaskan untuk kesediaan menguji.

Tabel 1 Data Implementasi Kesediaan Mengajar Melalui Web Application

\begin{tabular}{|c|c|c|c|c|c|c|c|c|c|}
\hline \multirow{3}{*}{ Periode } & \multicolumn{7}{|c|}{ Isi Kesediaan Mengajar } & \multirow{3}{*}{$\begin{array}{l}\text { Tidak } \\
\text { Mengisi }\end{array}$} & \multirow{3}{*}{$\%$} \\
\hline & \multirow{2}{*}{$\begin{array}{c}\text { Melalui } \\
\text { Web }\end{array}$} & \multirow{2}{*}{$\%$} & \multicolumn{4}{|c|}{ Melalui Form } & \multirow{2}{*}{ \% Mengisi } & & \\
\hline & & & Dosen Lama & $\%$ & Dosen Baru & $\%$ & & & \\
\hline $2007 / 2$ & 516 & $57,21 \%$ & 294 & $32,59 \%$ & 16 & $1,77 \%$ & $91,57 \%$ & 76 & $8,43 \%$ \\
\hline $2008 / 1$ & 697 & $65,69 \%$ & 145 & $13,67 \%$ & 124 & $11,69 \%$ & $91,05 \%$ & 95 & $8,95 \%$ \\
\hline
\end{tabular}

Pada Tabel 1 implementasi kesediaan mengajar belumlah dilakukan secara penuh 100\% karena masih dalam tahap transisi dan pengenalan aplikasi. Namun terlihat bahwa terdapat peningkatan dari periode 2007/2 ke periode 2008/1 dan hal ini terjadi terus menerus pada periode 
selanjutnya di mana sudah tidak digunakan lagi formulir untuk proses tersebut. Dari data di atas, didapatkan rincian efisiensi penggunaan waktu dan sumber daya dalam satu tahun sebagai berikut:

Penggunaan waktu $=((516+697): 2) \times 11$ detik $=1$ jam 52 menit

Penggunaan kertas $=((516+697): 2) \times$ Rp. $65,-=$ Rp. 39.400,-

Penggunaan tinta $=((516+697): 2) \times$ Rp. $150,-=$ Rp. 90.975,-

Tabel 2 Data Implementasi Kesediaan Menguji Melalui Web Application

\begin{tabular}{cccccccc}
\hline \multirow{2}{*}{ Periode } & \multicolumn{9}{c}{ Isi Kesediaan Menguji } & \multicolumn{2}{c}{ Tidak } \\
\cline { 2 - 7 } & $\begin{array}{c}\text { Melalui } \\
\text { Web }\end{array}$ & $\%$ & $\begin{array}{c}\text { Melalui } \\
\text { Form }\end{array}$ & $\%$ & $\begin{array}{c}\text { \% } \\
\text { Mengisi }\end{array}$ & Mengisi & \% \\
\hline $2007 / 1$ & 264 & $79,04 \%$ & 61 & $18,26 \%$ & $97,31 \%$ & 9 & $2,69 \%$ \\
\hline $2007 / 2$ & 340 & $99,13 \%$ & - & - & $99,13 \%$ & 3 & $0,87 \%$ \\
\hline
\end{tabular}

Tabel 2 menjelaskan efektifitas implementasi kesediaan menguji melalui web application di mana pada periode $2007 / 2$, aplikasi sudah digunakan secara menyeluruh, sehingga tidak dibutuhkan formulir untuk mendapatkan data kesediaan menguji dosen. Rincian efisiensi penggunaan waktu dan sumber daya dalam satu tahu, dapat dilihat sebagai berikut:

Penggunaan waktu $=((264+340): 2) \times 11$ detik $=55$ menit

Penggunaan kertas $=((264+340): 2) \times$ Rp. $65,-=$ Rp. 19.600,-

Penggunaan tinta $=((264+340): 2) \times$ Rp. $150,-=$ Rp. 45.300,-

Seperti telah dijelaskan sebelumnya, bahwa melalui web application, dosen tidak hanya dapat memberikan data kesediaan waktu yang dimiliki, namun juga dapat menerima informasi beberapa informasi secara online. Hal ini memberikan kemudahan bagi dosen dan meningkatkan layanan kepada dosen. Tabel 3 menjelaskan efisiensi penggunaan waktu dan sumber daya dalam setahun yang didapat dengan diimplementasikannya layanan informasi melalui web application.

Tabel 3 Efisiensi untuk Layanan Informasi

\begin{tabular}{|c|c|c|c|}
\hline Informasi & Efisiensi Waktu & Efisiensi Kertas & Efisiensi Tinta \\
\hline Jadwal mengawas ujian & 2 jam 45 menit & Rp. 450.800,- & Rp. 1.050.000,- \\
\hline $\begin{array}{l}\text { Rincian transaksi dan honor membimbing } \\
\text { dan menguji }\end{array}$ & 2 jam 30 menit & Rp. 162.500,- & Rp. $195.000,-$ \\
\hline Prosedur dan petunjuk skripsi & $1 \mathrm{jam}$ & Rp. 418.600,- & Rp. $\quad 975.000,-$ \\
\hline
\end{tabular}

Dengan diimplementasikannya web application dalam proses koordinasi data dan informasi dengan dosen, didapatkan beberapa manfaat sebagai berikut: (1) kemudahan bagi dosen dalam memberikan data, yaitu data kesediaan mengajar dan menguji; (2) kemudahan bagi dosen dalam mendapatkan informasi, yaitu informasi jadwal mengawas, menguji, rincian transaksi dan honor membimbing dan menguji, prosedur dan petunjuk skripsi, hasil isian kesediaan; (3) peningkatan efisiensi kerja, yaitu proses pencetakan berkas, setting berkas, distribusi berkas dan entri data; (4) peningkatan efisiensi sumber daya, yaitu kertas, tinta, biaya lembur staf; (5) meniadakan keluhan, yaitu keluhan atas berkas tidak diterima oleh dosen, proses pencetakan ulang berkas, dan pemberian informasi ulang. Manfaat ini adalah manfaat yang bersifat intangible.

\section{Interface}

Berikut ini adalah beberapa interface pada web application yang menjadi media komunikasi dua arah antara dosen dan staf pengelola (Gambar $4-11)$. 


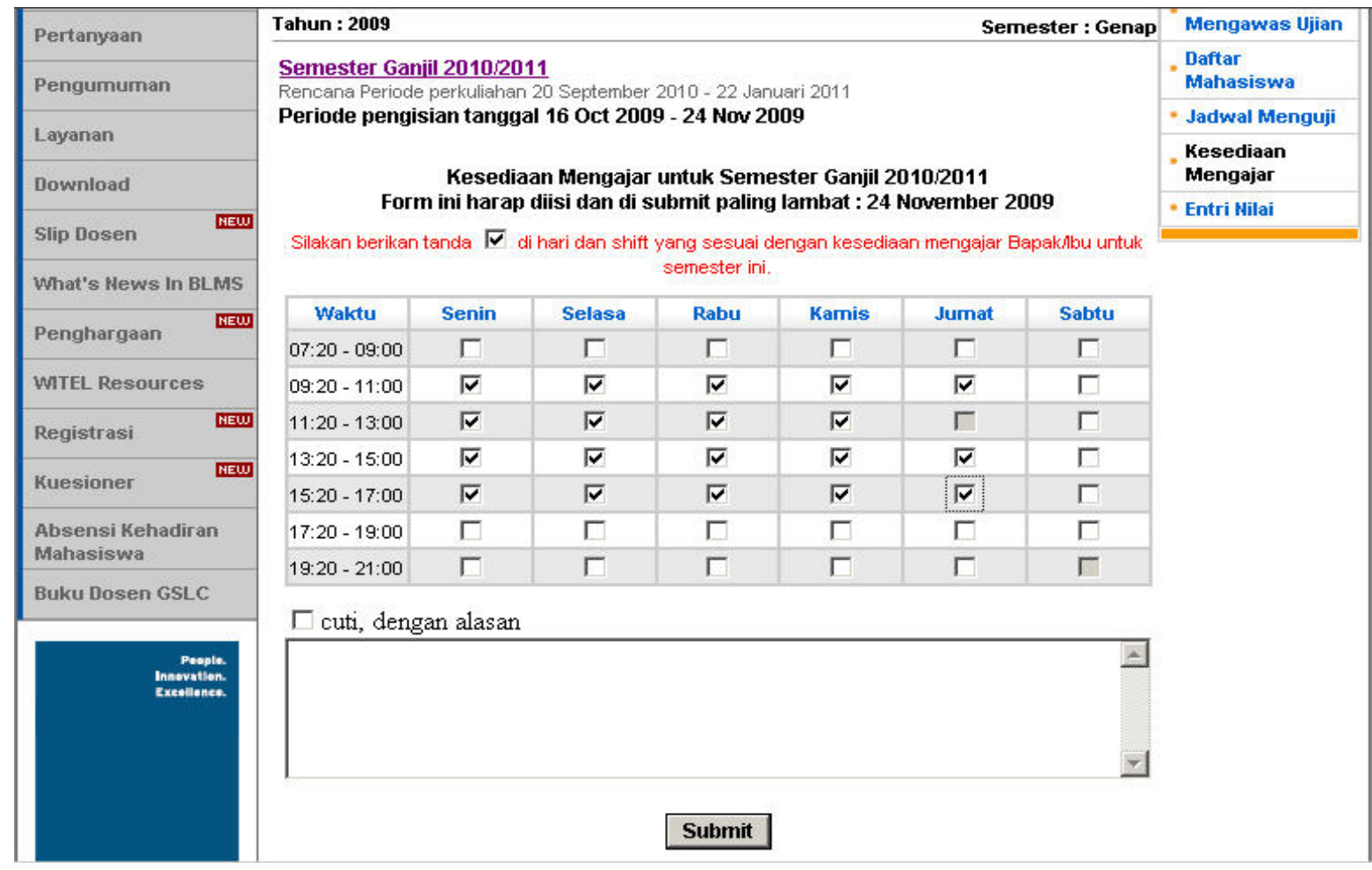

Gambar 4 Tampilan isian kesediaan mengajar oleh dosen

Gambar 4 di atas menunjukkan tampilan isian kesediaan mengajar yang tampil pada http://binusmaya.binus.ac.id. Dosen diberikan kemudahan dengan memberikan tanda centang $(\sqrt{ })$ pada waktu yang sesuai dengan kesediaan dosen. Dosen juga diberikan fasilitas untuk mengajukan cuti mengajar dengan melakukan tanda centang pada tempat yang disediakan dan mengetikan alasan dari cuti yang diajukan. Setelah dosen meng-klik tombol submit, maka data akan tersimpan pada web server. Staf akan melakukan sinkronisasi data melalui aplikasi dan pada saat itulah data pada web server ditransfer ke database server. Tampilan hasil isian dosen dapat dilihat melalui aplikasi yang ada pada staf pengelola seperti pada Gambar 5.

Gambar 6 menunjukkan tampilan isian kesediaan menguji. Sama seperti kesediaan mengajar, dosen dengan mudah melakukan pengisian pada waktu yang sesuai dengan kesediaan menguji dosen dan meng-klik tombol submit.

Untuk melihat informasi jadwal mengawas ujian, dosen bisa mendapatkan pada menu yang telah disediakan di http://binusmaya.binus.ac.id. Gambar 7 menunjukkan tampilan dari informasi jadwal mengawas ujian mata kuliah yang ditugaskan kepada dosen. Umumnya jadwal mengawas ujian adalah jadwal ujian dari kelas yang dipegang oleh dosen tersebut.

Gambar 8 menunjukkan informasi jadwal menguji skripsi yang dapat diketahui oleh dosen. Informasi tanggal, waktu, lokasi, dan judul dari skripsi yang akan diuji ditampilkan dengan sangat jelas. 


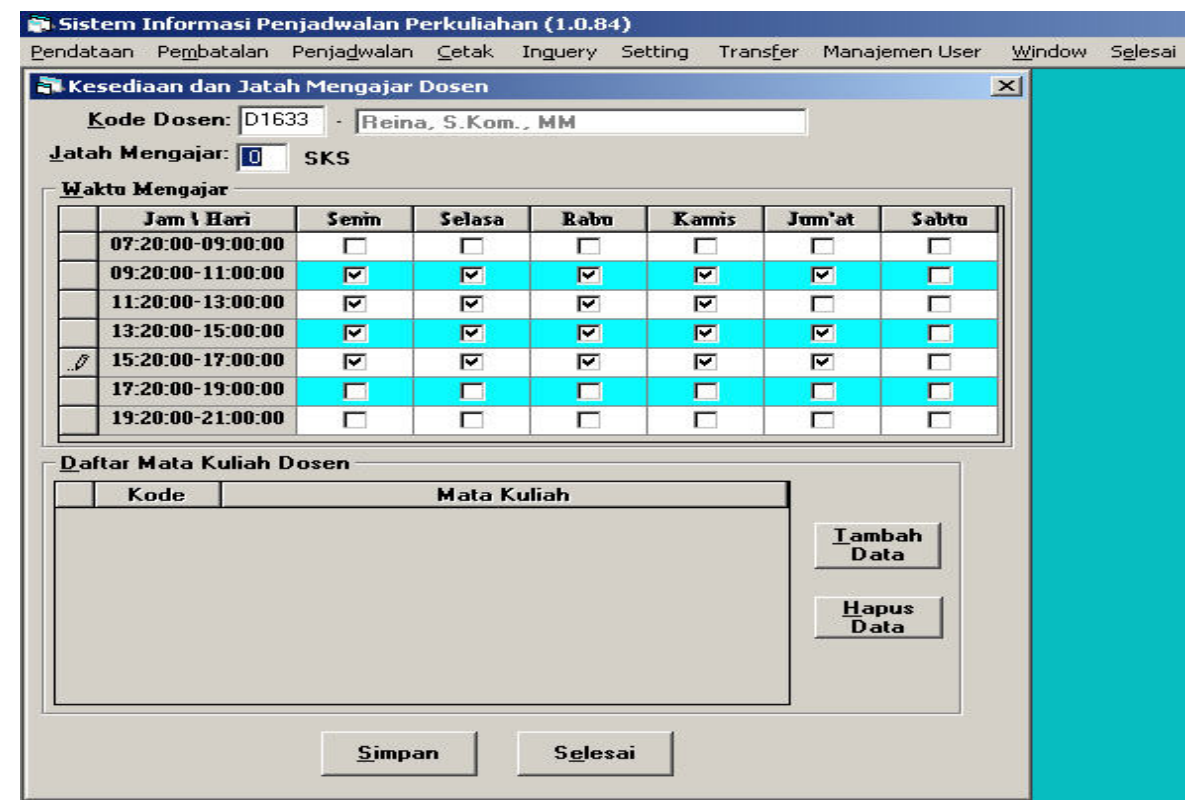

Gambar 5 Tampilan hasil isian kesediaan mengajar dosen yang ada pada aplikasi staf

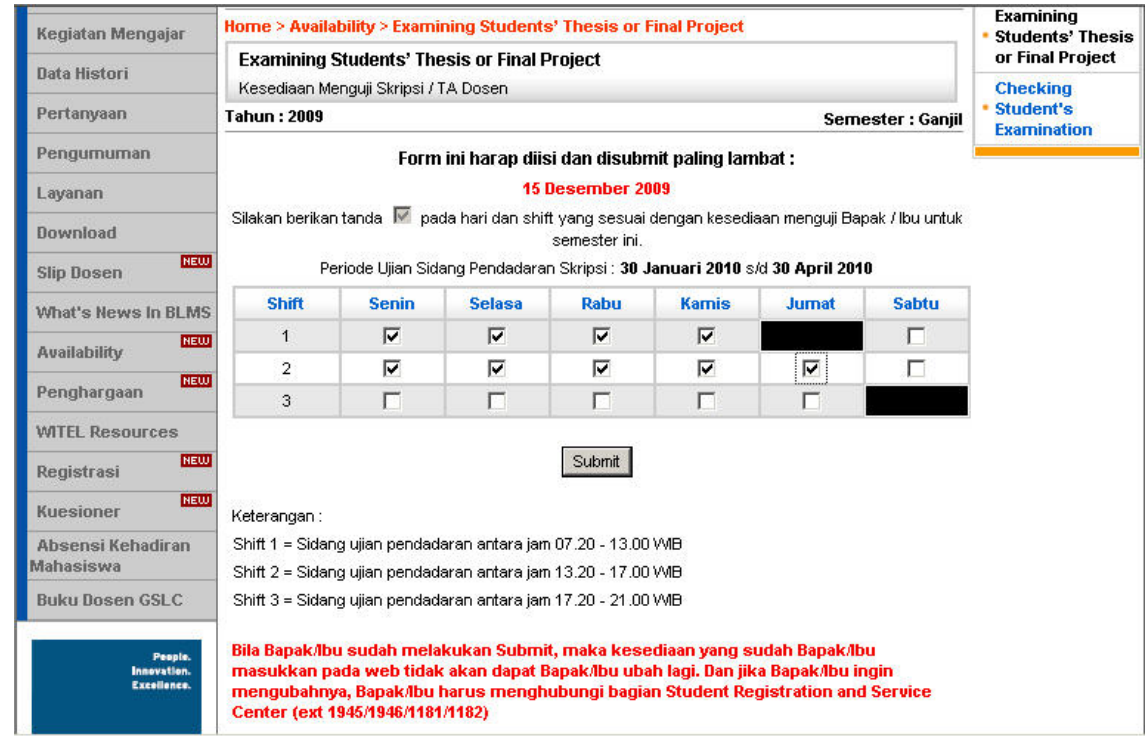

Gambar 6 Tampilan isian kesediaan menguji oleh dosen

Gambar 9 dan Gambar 10 menunjukkan rincian transaksi dan honor membimbing dan menguji skripsi yang telah dilakukan oleh dosen. Sebelum tampil daftar rincian tersebut, dosen diminta untuk mengisi periode rincian honor yang diinginkan. Periode yang diisi berupa pilihan bulan dan tahun dari rincian yang ingin diketahui. Dalam daftar transaksi membimbing, diinformasikan pula nama-nama mahasiswa hasil bimbingan dari dosen yang telah lulus ujian skripsi. Sedangkan dalam daftar rincian honor menguji, diinformasikan secara detail transaksi pelaksanaan ujian skripsi yang telah dilakukan oleh dosen sebagai penguji.

Gambar 11 menunjukkan kemudahan dalam men-download petunjuk dan prosedur skripsi pada http://binusmaya.binus.ac.id. 


\section{PENUTUP}

Penerapan web application telah membantu meningkatkan efisiensi dan efektifitas layanan kepada dosen. Sehingga koordinasi data dan informasi dari dan kepada dosen dapat dilakukan dengan mudah, cepat, dan cukup dengan penggunaan waktu dan sumber daya yang relatif sedikit. Lima manfaat dari diterapkannya web application pada layanan dosen ini adalah kemudahan bagi dosen dalam memberikan data, mendapatkan informasi, meningkatkan efisiensi kerja staf, meningkatkan efisiensi penggunaan sumber daya, dan meningkatkan layanan kepada dosen dengan meniadakan keluhan dari dosen.

Melalui web application dosen diberikan keleluasaan dalam memberikan data dan mendapatkan informasi terkait dengan data kesediaan mengajar, data kesediaan menguji, informasi jadwal mengawas, jadwal menguji, dan informasi rincian transaksi serta honor membimbing dan menguji secara cepat dan mudah.

\section{DAFTAR PUSTAKA}

Suryane, Y. (2011). Sistem Informasi Akademik Berbass Web Di SMA Negeri 1 Sukaresmi Cianjur. Diakses Februari 24, 2012, from Unikom Scholar Directory: http://dir.unikom.ac.id

Wall, L., \& Lader, A. (2002). Building Web Services and .NET Applications. California: McGraw-Hill. 


\section{APPENDIX}

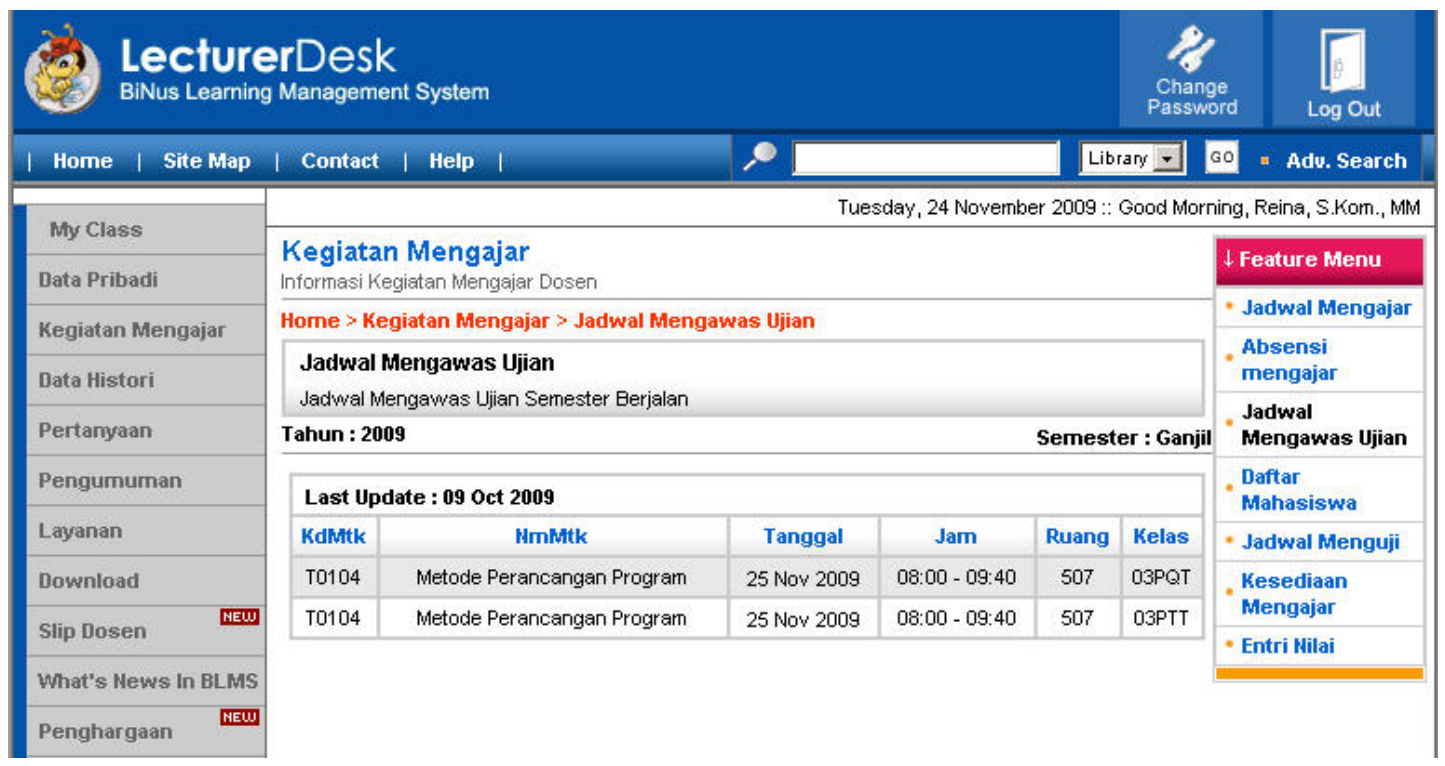

Gambar 7 Tampilan informasi jadwal mengawas ujian.

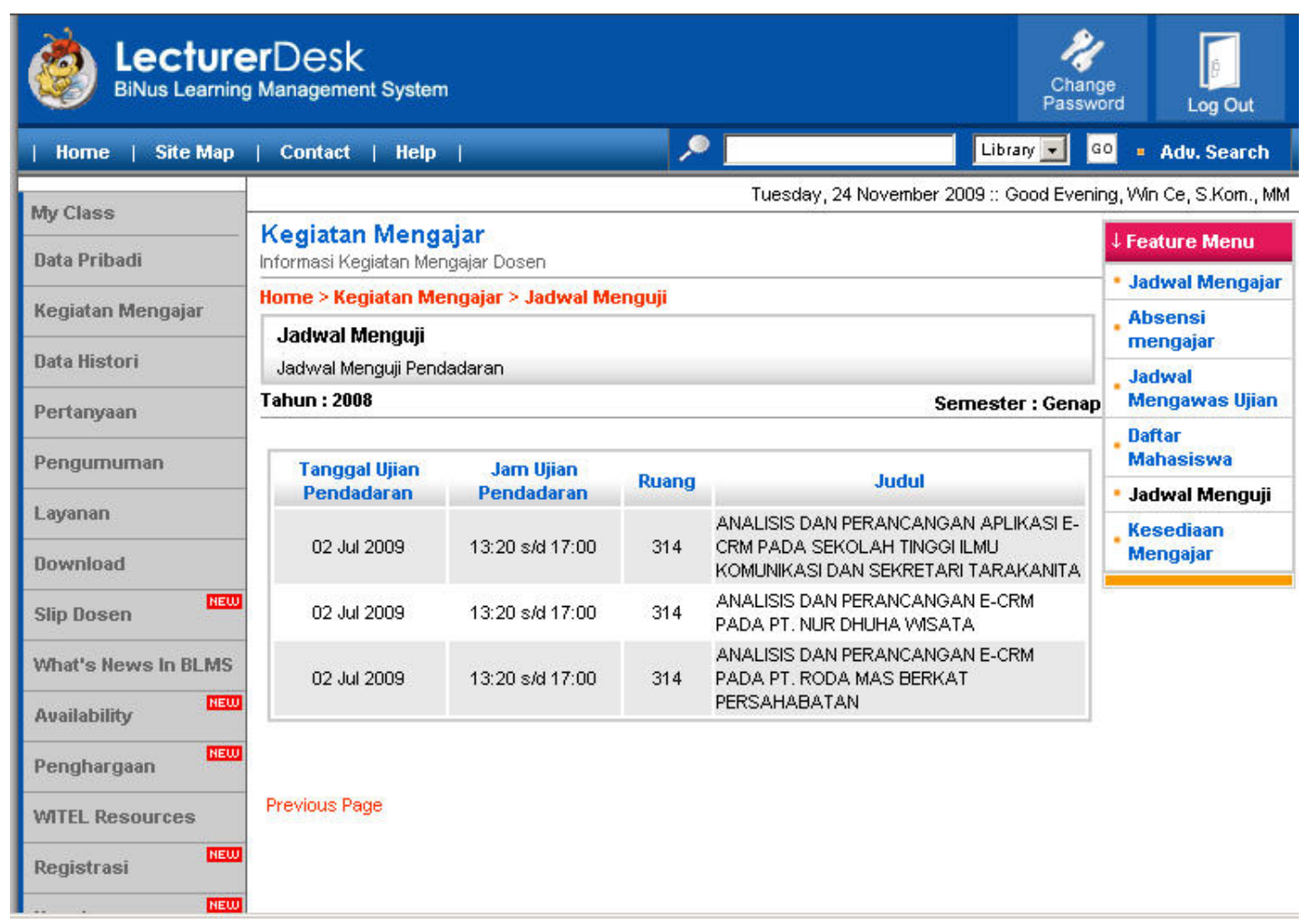

Gambar 8 Tampilan informasi jadwal menguji skripsi. 


\begin{tabular}{|c|c|c|c|c|c|}
\hline Data Pribadi & \multicolumn{4}{|l|}{$\begin{array}{l}\text { Slip Dosen } \\
\text { Slip Dosen }\end{array}$} & \multirow{3}{*}{\begin{tabular}{|l|}
$\downarrow$ Feature Henu \\
Honor \\
- Membimbing \\
Skripsi/TA
\end{tabular}} \\
\hline Kegiatan Mengajar & \multicolumn{4}{|c|}{ Home $>$ Slip Dosen $>$ Honor Membimbing Skripsi/TA } & \\
\hline \multirow{2}{*}{ Data Histori } & \multirow{2}{*}{\multicolumn{4}{|c|}{$\begin{array}{l}\text { Honor Membimbing Skripsi/TA } \\
\text { Honor Membirmbing SkripsirTA. }\end{array}$}} & \\
\hline & & & Honor Membimbing SkripsirTA & & \multirow{2}{*}{$\begin{array}{l}\text { Honor Menguji } \\
\text { Skripsi/TA }\end{array}$} \\
\hline Pertanyaan & \multicolumn{4}{|c|}{ Semester : Genap } & \\
\hline Pengurnuman & \multicolumn{4}{|c|}{ Silahkan memilih bulan dan tahun honor yang ingin ditampilkan! } & - Honor Dosen \\
\hline Layanan & \multicolumn{4}{|c|}{ Bulan dan tahun honor(month-year) $07-2009$} & \\
\hline Download & \multicolumn{4}{|l|}{ View } & \\
\hline $\begin{array}{l}\text { Slip Dosen } \\
\text { What's News In BLMS }\end{array}$ & \multicolumn{4}{|c|}{$\begin{array}{l}\text { DAFTAR RINCLAN HONOR MEMBIMBING SKRIPSI / TUGAS } \\
\text { PERIODE GENAP 2008 / } 2009 \\
\text { JULI } 2009\end{array}$} & \\
\hline Auailability & \multirow{3}{*}{$\begin{array}{l}\text { Kode Dosen } \\
\text { Nama } \\
\text { Jeris Bimbingan }\end{array}$} & \multirow{3}{*}{$\begin{array}{l}\text { D2434 } \\
\text { : Win Ce, S.Kom., MM } \\
\text { :Sknipsi Jalur Khusus }\end{array}$} & & & \\
\hline Penghargaan MEW & & & & & \\
\hline WITEL Resources & & & & & \\
\hline \multirow{2}{*}{$\begin{array}{ll}\text { Registrasi } & \text { HEW } \\
\text { Kuesioner } & \text { HEW }\end{array}$} & NIM & Nama Mahasiswa & Kelas & Status & \\
\hline & 0800749052 & NICO RIBOYO BARUS & KHS & & \\
\hline \multirow{2}{*}{$\begin{array}{l}\text { Absensi Kehadiran } \\
\text { Mahasiswa }\end{array}$} & 0800776311 & KAREL KAWENGIAN INTAN LANGI & KHS & & \\
\hline & 0900793981 & NATALLIA MELANY & KHS & & \\
\hline Buku Dosen GSLC & 0900804291 & ASTRID KARINA & KHS & & \\
\hline \multirow{3}{*}{ 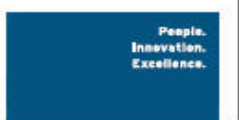 } & 0900830131 & GILANG BAYU PERDANA & KHS & $\checkmark$ & \\
\hline & (1) & & & 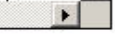 & \\
\hline & Print & & & & \\
\hline
\end{tabular}

Gambar 9 Rincian transaksi dan honor membimbing skripsi.

\begin{tabular}{|c|c|c|c|c|c|c|c|c|}
\hline \multirow{2}{*}{ Data Pribadi } & \multirow{2}{*}{\multicolumn{7}{|c|}{$\begin{array}{l}\text { Slip Dosen } \\
\text { Slip Dosen }\end{array}$}} & \multirow{4}{*}{$\begin{array}{l}\downarrow \text { Feature Menu } \\
\text { Honor } \\
\text { - Membimbing } \\
\text { Skripsi/TA }\end{array}$} \\
\hline & & & & & & & & \\
\hline Kegiatan Mengajar & \multicolumn{7}{|c|}{ Home $>$ Slip Dosen $>$ Honor Menguji Skripsi/TA } & \\
\hline \multirow{2}{*}{ Data Histori } & \multirow{2}{*}{\multicolumn{7}{|c|}{$\begin{array}{l}\text { Honor Menguji Skripsi/TA } \\
\text { Honor Menguji SkripsirTA }\end{array}$}} & \\
\hline & & & & & & & & \multirow{2}{*}{$\begin{array}{l}\text { Honor Menguji } \\
\text { Skripsi/TA }\end{array}$} \\
\hline Pertanyaan & \multicolumn{7}{|c|}{ Semester : Genap } & \\
\hline Pengumuman & \multirow{2}{*}{\multicolumn{7}{|c|}{$\begin{array}{l}\text { Silahkan memilih bulan dan tahun honor yang ingin ditampilkan! } \\
\text { Bulan dan tahun honor (month-year) } 07-2009\end{array}$}} & \multirow{3}{*}{ - Honor Dosen } \\
\hline Layanan & & & & & & & & \\
\hline Download & \multicolumn{7}{|l|}{ View } & \\
\hline Slip Dosen & \multirow{5}{*}{\multicolumn{7}{|c|}{$\begin{array}{c}\text { Daftar Rincian Honor Menguji Skripsi/Tugas } \\
\text { Bulan Juli } 2009\end{array}$}} & \\
\hline What's News in BLMS & & & & & & & & \\
\hline Availability & & & & & & & & \\
\hline \multirow{2}{*}{$\begin{array}{l}\text { Penghargaan HEW } \\
\text { WITEL Resources }\end{array}$} & & & & & & & & \\
\hline & & & & & & & & \\
\hline \multirow{2}{*}{ Registrasi } & \multirow{2}{*}{ Jenis Bimbingan } & \multirow{2}{*}{ Jurusan } & \multirow{2}{*}{ Tanggal } & \multirow{2}{*}{ Jam } & \multirow{2}{*}{ Ruang } & \multicolumn{2}{|c|}{ Jumlah } & \\
\hline & & & & & & Mhs & Jud & \\
\hline Kuesioner & 1 - Skripsi Kelas & 22 - Sistem Informasi & $02-07-2009$ & $13: 20: 00$ & 314 & 8 & 争 & \\
\hline \multicolumn{8}{|l|}{$\begin{array}{l}\text { Absensi Kehadiran } \\
\text { Mahasiswa }\end{array}$} & \\
\hline Buku Dosen GSLC & & & & & & & & \\
\hline $\begin{array}{l}\text { Peoplo. } \\
\text { Innowation. } \\
\text { Exeolliones. }\end{array}$ & 11 & & & & & & 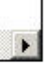 & \\
\hline & Print & & & & & & & \\
\hline
\end{tabular}

Gambar 10 Rincian transaksi dan honor menguji skripsi. 


\begin{tabular}{|c|c|c|}
\hline \multirow{2}{*}{ Kegiatan Mengajar } & \multicolumn{2}{|l|}{ Home $>$ Download } \\
\hline & Tahun : 2009 & Semester : Ganjil \\
\hline Data Histori & \multirow{3}{*}{\multicolumn{2}{|c|}{$\begin{array}{l}\text { Prosedur dan Petunjuk Skripsi/Tugas Akhir } \\
\text { 1. Pedoman Penyusunan Skripsi Manajemen Ganjil } 2009 \\
\text { Tanggal Update : } 14 \text { Jul 2009 11:10:16 AM }\end{array}$}} \\
\hline Pertanyaan & & \\
\hline Pengumuman & & \\
\hline Layanan & $\begin{array}{l}\text { 2. Pedoman Penyusunan Skripsi Manajemen Sem. Genap } 09 \\
\text { Tanggal Update : } 10 \text { Oct 2009 15:08:03 PM }\end{array}$ & \\
\hline Download & \multirow{2}{*}{$\begin{array}{l}\text { 3. Prosedur Skripsi Akuntansi Sem. Ganiil 09/10 } \\
\text { Tanggal Update : } 01 \text { Sep 2009 17:25:08 PM }\end{array}$} & \\
\hline Slip Dosen & & \\
\hline What's News in BLMS & $\begin{array}{l}\text { 4. Prosedur Skripsi Akuntansi Sem. Ganjil 09/10 } \\
\text { Tanggal Update : } 01 \text { Sep } 2009 \text { 17:25:35 PM }\end{array}$ & \\
\hline Penghargaan HEW & \multirow{3}{*}{$\begin{array}{l}\text { 5. Prosedur Skripsi Fasilkom Sem. Ganjil 09/10 } \\
\text { Tanggal Update : } 01 \text { Sep } 2009 \text { 17:29:38 PM } \\
\text { 6. Prosedur Skripsi Wutk \& Stat Sem. Ganjil 09/10 } \\
\text { Tanggal Update : } 21 \text { Nov } 2009 \text { 13:28:54 PM }\end{array}$} & \\
\hline WITEL Resources & & \\
\hline Registrasi & & \\
\hline Kuesioner & $\begin{array}{l}\text { 7. Prosedur Skripsi Program Ganda Sem. Ganjil 09/10 } \\
\text { Tanggal Update: } 01 \text { Sep 2009 17:30:39 PM }\end{array}$ & \\
\hline $\begin{array}{l}\text { Absensi Kehadiran } \\
\text { Mahasiswa }\end{array}$ & \multirow[t]{2}{*}{$\begin{array}{l}\text { 8. Prosedur Skripsi Sastra China Sem. Ganijl 09/10 } \\
\text { Tanggal Update: } 23 \text { Nov } 2009 \text { 11:29:31 AM }\end{array}$} & \\
\hline Buku Dosen GSLC & & \\
\hline 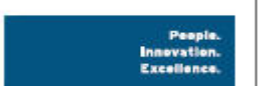 & $\begin{array}{l}\text { 10. Prosedur Skripsi Sastra Jepang Sem. Ganjil 09/10 } \\
\text { Tanggal Update: } 08 \text { Sep 2009 18:01:52 PM }\end{array}$ & \\
\hline
\end{tabular}

Gambar 11 Tampilan download petunjuk dan prosedur skripsi. 